\title{
Time keeping in female Myotis emarginatus during reproduction (Chiroptera: Vespertilionidae)
}

\author{
Hospodaření časem samicemi netopýra brvitého (Myotis emarginatus) během \\ rozmnožování (Chiroptera: Vespertilionidae)
}

\section{Friederike SPITZENBERGER \& Edmund WEISS}

BatLife Österreich, Landstraßer Hauptstraße 139/15, AT-1030 Wien, Austria; friederike.spitzenberger@batlife.at

received on 3 August 2020

\begin{abstract}
In the years 2012-2017, we studied the annual and diel temporal activity patterns exhibited by female Geoffroy's bats (Myotis emarginatus) during reproduction by using an infrared light barrier system, videotaping with an infrared camera and sporadic direct counts of juveniles in the roost when the adult bats were not present. We determined the effect of weather on timing and duration of maternity roost occupancy, reproductive periods, return and emergence flights and amount of time spent outside the roost, and estimated the yearly reproductive output. Contrary to the considerable effects of weather conditions on the reproduction phenology in Myotis daubentonii and M. nattereri, timing and duration of reproductive activities of $M$. emarginatus were remarkably similar over the study period despite distinct inter-annual differences in the occurrence of inclement weather spells causing food shortages and use of torpor. Pregnancy, lactation and roost occupation by adult females were completed every year within 10 to 11 weeks. Adverse spring weather bouts caused considerable fluctuations in the duration of colony formation during early pregnancy, but did not influence the total duration of the pregnancy period. The mean durations of both the emergence and return flights were markedly similar over the study years. An exception was the distinct increase in duration of emergence flight during pregnancy in 2016 and 2017 which might be related to increased colony numbers. With the exception of the year 2015, the standard deviations of emergence flights were small, but in contrast to the quite scheduled return flights during lactation, the mean durations of return flights during pregnancy varied strongly. The return flights executed by juveniles during post-lactation were highly irregular. The mean time spent outside the roost was quite similar over the study years. The estimated yearly reproductive output was low $(<52 \%)$ and the proportion of non-reproductive females in the maternity colony high. Nevertheless, the colony numbers increased considerably over the study period. The relevance of keeping the annual and diel activity patterns rather inflexible and of an effective social thermoregulation in relation to a trade-off between survival and reproduction are discussed.
\end{abstract}

Key words. Phenology, reproduction, life history, circannual clock, Myotis emarginatus.

\section{INTRODUCTION}

Allocating the right amount of time to different activities despite extrinsic constraints is crucial to an individual's survival and reproduction (HALLE \& STENSETH 2000). This applies especially to female bats living in seasonal environments where pregnancy and lactation are restricted to a relatively short period between arousal from hibernation during spring and mating, and 
pre-hibernation fattening in autumn (Kunz \& STERn 1995, Kunz et al. 1998, Hood et al. 2002). Females coping with increasing energy demands during gestation and even considerably higher demands during lactation (RACEY \& SPEAKMAN 1987) are constrained by fluctuations in food availability due to fluctuating ambient temperature and precipitation which usually exert a strong influence on timing and duration of reproductive activities in temperate bat species (RACEY 1969, 1973). The need to partition limited time and energy to different activities often leads to trade-offs between the life-history traits, i.e. reproduction and individual survival (STEARNS 1989, RANSOME 1995). The high energetic costs of reproduction can result in reduced success during the current reproductive season, but also in reduced fecundity in the following year and in the long term in reduced survival of reproductive females (Moyes et al. 2011).

Conversely, allocating time to a long hibernation period is beneficial for individual survival as hibernating bats are concealed from factors of extrinsic mortality and derive a benefit from retarded physiological deterioration. A long hibernation period is considered to be an important factor explaining the exceptional longevity of bats (WILKInSON \& South 2002, TurbiLl et al. 2011, GEISER 2013).

For a successful and timely completion of the main biological processes - hibernation, reproduction, mating, and pre-hibernal fat accumulation - temperate bats need to be optimally adapted to the periodic change of seasons. For achieving this, they rely on time-keeping mechanisms consisting of an internal annual pacemaker, the circannual clock, which works like a calendar of the annual environmental cycle (ERKERT 1982, Hut et al. 2014). The circannual clock is synchronised with the environmental cycle by external cues (Zeitgeber) such as changes in day-length (photoperiod) or e.g. ambient temperature and food availability. The extent of reliance on external cues is species specific. Some species rely only on the internal clock synchronised with the photoperiod, in many other species the onset and termination of biological processes depend on environmental factors such as predation and weather etc. which makes timing highly flexible. Using the photoperiod as an external cue for synchronisation of internal and external cycles produces a rather inflexible time schedule (ERKERT 1982). Besides the internal circannual rhythm of organisms, an internal circadian rhythm guides the diel activities in a species and ensures synchronisation of activities in all individuals.

By spending large parts of the year in hibernation and terminating reproduction within a short space of time, Myotis emarginatus (Geoffroy, 1806) seems to take a special position in the trade-off between reproduction and survival in comparison to congeneric species of a similar body mass and life expectancy. Myotis emarginatus is well known for having a very long (up to seven months) hibernation period (TOPÁL 2001, KRETZSCHMAR 2003). The immigration process of M. emarginatus into a hibernaculum can be already completed at the end of September (Kugelschafter \& Hensle 2017). A corresponding short reproductive period has already been indicated by previous studies (e. g. Richarz et al. 1989, Kretzschmar 2003). The aim of our six-year study was to provide evidence on the brevity of the reproductive period and to elucidate the mechanisms which enable the bats to complete reproduction early and in a timely fashion.

\section{MATERIAL AND METHODS}

\section{Study site and date}

In the years 2012-2017, we conducted studies of a maternity colony of Geoffroy's bats in a castle in Lockenhaus $\left(47^{\circ} 24^{\prime} \mathrm{N}, 16^{\circ} 51^{\prime} \mathrm{E}, 353 \mathrm{~m}\right.$ a. s. 1.) in Burgenland, south-eastern Austria. The castle is situated in the trans-national Geschriebenstein-Irrotkö Nature Park at the foot of the Günser mountains near the 
Austrian-Hungarian border. The climate is mild and humid. The castle and surroundings are protected as a Natura 2000 site under EU legislation. The maternity roost is a chamber in one of the lofts situated under a partly north facing and partly south-east facing roof offering a range of roost temperatures $\left(\mathrm{T}_{\mathrm{r}}\right)$. It has only one access window. During the study period, the mean diel roost $\mathrm{T}_{\mathrm{r}}$ varied from $24.5^{\circ} \mathrm{C}$ to $26.3{ }^{\circ} \mathrm{C}$; the highest $\mathrm{T}_{\mathrm{r}}$ was $41.5^{\circ} \mathrm{C}$, the lowest $4.5^{\circ} \mathrm{C}$. In total, we studied the bats for $57924 \mathrm{~h}$-days.

\section{Dat a collection}

For recording the flight movements into and from the roost and numbers of individuals in the colony, we installed infrared light barriers (ChiroTEC, Type LIBA $16 \mathrm{n}$ ) connected to a logger (Tricorder 9008) in the frame of the single access window. Both the transmitter and the receiver element consist of two parallel (distance $35 \mathrm{~mm}$ ) light curtains, each equipped with 16 infrared light beams spacing $18 \mathrm{~mm}$. The sequence of disconnections triggered by passing objects determines the recorded flight direction. To be registered, objects must be large enough to touch both light curtains at the same time. The minimum detectable distance between passing objects is thus $>35 \mathrm{~mm}$, the maximum tested speed of passing objects to be detected is $20 \mathrm{~m} / \mathrm{s}$.

The fact that Geoffroy's bats leave the roost singly at almost regular intervals improves the reliability of results of the registrations. We tested the reliability of the registrations of returning bats recorded by the light barrier system by using a sample of simultaneously recorded light barrier registrations and IR-video recordings obtained at the roost entrance in the year 2011. This sample covers sequences of the daily return flights during five nights between 6 and 14 June. We found no statistically significant difference between the number of visually recorded entry events $(n=85)$ and the number of entry events automatically recorded by the light barrier $(\mathrm{n}=86)$ within the same time intervals (Wilcoxon signed-ranks test with continuity correction, $\mathrm{V}=1, \mathrm{p}=1$ ).

We registered the following data: (1) dates of annual initial arrival of pregnant females in and final departure of adults and juveniles from the maternity roost; (2) timing and duration of pregnancy, lactation and post-lactation periods; (3) timing and duration of daily emergence, return and time spent outside the roost; and (4) numbers of colony members.

During the roosting periods 2012-2017 we obtained a total of 701,529 registrations of bat passes through the access window. For eight days in May 2012 (17, 21-25, 28, 29), the light barriers did not function.

We recorded ambient $\left(\mathrm{T}_{\mathrm{a}}\right)$ and roost temperatures $\left(\mathrm{T}_{\mathrm{r}}\right)$ at hourly intervals by using automatic temperature sensors. The temperature sensor recording $T_{a}$ was positioned in the frame of the access window, that recording $T_{\mathrm{r}}$ near a beam in the loft where the colony mostly roosted. We calculated median temperatures of the two diel periods by using $T_{a}$ for the period spent outside the roost and $T_{r}$ for the period spent inside the roost.

In 2012 and 2017, we observed activities of the colony members by using infrared cameras positioned in the roost. We entered the roost irregularly in 2012, 2013, and 2014, and regularly in 2017 after the adult females had left for foraging to count living young, aborted foetuses and dead young.

\section{Definitions}

Objects of observation. As maternity colonies of Myotis emarginatus are composed of females only (BAUER 1957, GAISLER 1971) and single males have been found roosting separated from the colony (STECK \& BRINKMANN 2015), we treated all adult bats observed during pregnancy and lactation as females which either participated in the reproductive process ("reproductive females") or for any reason did not participate ("non-reproductive females"). Bats observed during post-lactation were mainly juveniles as adult females left the roost soon after weaning.

Timing and duration of roost occupancy, return and emergency, time spent outside the roost; diel periods. As the initial arrival date in the maternity roost we used the earliest day in April on which a group 
of at least 10 bats arrived in the roost, and as the final departure date that day in late July or early August on which for the last time in a year 20 or more bats returned to the roost.

Calculation of timing and duration of emergence and return flights was restricted to nights in which a minimum number of ten colony members emerged from and returned to the roost, respectively. As the start of the evening emergence we defined the time when $5 \%$ of all emerging bats had left the roost; the time when $95 \%$ of all bats had left the roost was taken as the end of the emergence. Analogously, the start of the return flights was defined as the time when $5 \%$ of all returning bats had entered the roost, the end of the return was defined as the time when $95 \%$ of all bats were in the roost. Based on the results obtained by analysing the timing of emergence and return, we determined two diel periods, one spent outside the roost (20:00-03:00 h) and the other one spent inside the roost (03:00-20:00 h).

The time the colony spent outside the roost was calculated by applying a refined version of the "area under the graph" method introduced by MAIER (1992). The maximum number of bats recorded (MB) was calculated as the maximum of the cumulative sum of all bats leaving (positive) and entering (negative) the roost during one night (i.e. individuals emerging from the roost), plus the absolute value of the minimum of the cumulative sum of all bats during the same time interval. The cumulative sum of all bats entering and leaving the roost over the course of one night was plotted and the mean time spent outside the roost per individual was estimated by dividing the area under the resulting graph by MB. The time an animal spent outside the roost is not equivalent to the time spent foraging (KRULL et al 1991).

All times are expressed as Coordinated Universal Time $(\mathrm{UTC}+01: 00$ hour $=\mathrm{CET})$. Sunrise and sunset times for the study locality were obtained from Geoscience Australia (http://www.ga.gov.au/geodesy/ astro/sunrise.jsp).

Classification of reproductive periods (pregnancy, lactation) and post-lactation. The term pregnancy was used for that part of the gestation period that was spent in the maternity roost. To divide the roost occupation time into the periods of (1) pregnancy which is subdivided in colony formation (prA) and (prB) after colony formation; (2) lactation; and (3) post-lactation, we used the data obtained by the infrared light barriers and visual observation. We defined the duration of the pregnancy period as the date between the initial arrival in the roost (at least 10 bats in the roost) and the onset of parturitions, notwithstanding the fact that parturitions occurred over a period as birthing was not synchronous. As the termination date of the colony formation we took that day which preceded the date at which the first peak number in the colony was reached.

We determined the start of the lactation period by a significant increase in the duration of intermediate flights. As intermediate flights we defined entering and leaving activities registered in the time interval between the earliest time when $95 \%$ of the bats in a particular night had left the roost and the latest time when $5 \%$ of bats returning to the roost in the same night had returned. During the lactation period, we interpreted these flights as nursing flights conducted by females which returned to the roost for suckling their young (Fig. 1a). We defined the start of the post-lactation period as the time when nursing flights ceased and the pattern of return flights became strikingly irregular (Fig. 1b). As the majority of adult females left the roost in an early phase of the post-lactation period (Fig. 1b), we interpreted these irregular return flights as flights performed by juveniles after weaning.

Calculation of the highest number of roost occupants. The average highest number of adult females per year was calculated from the five highest values recorded per year.

Estimation of the annual reproductive output and number of non-reproductive females in the colony. Juvenile mortality consisted of aborted foetuses and dead fledged and unfledged young found in the roost after the nightly departure of the colony. We defined the reproductive output as the percentage of the annual maximum numbers of living young per maximum annual number of adult females. To assess the relative magnitude of numbers of suckled pups and non-reproductive females in the years 2012-2016, we compared the numbers of light-barrier-recorded intermediate flights obtained in those years with that of 2017 when thorough visual counts of juveniles had been conducted (Fig. 5).

Data analysis. $\mathrm{R}$ was used for all statistical analyses. 

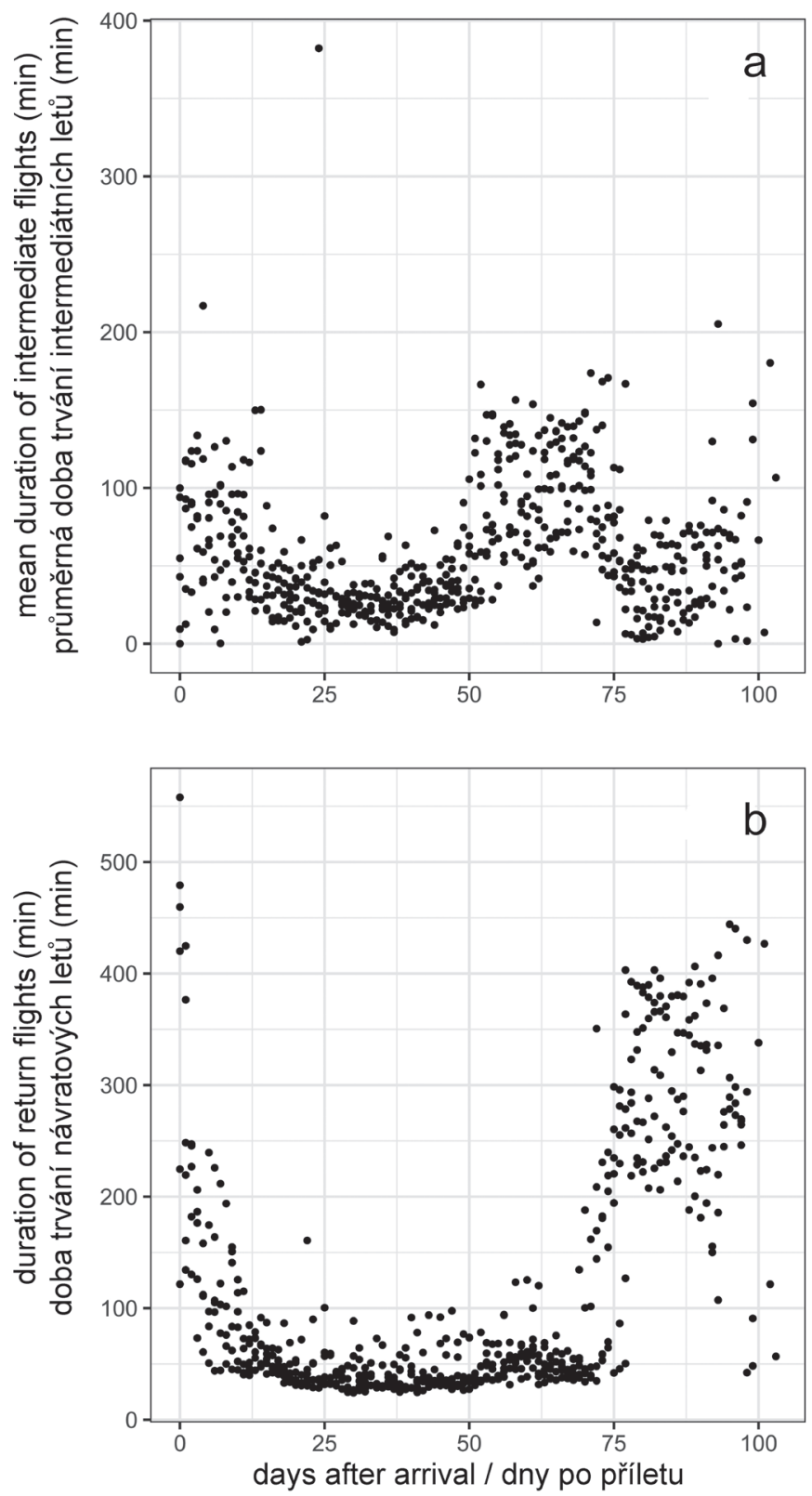

Fig. 1. Mean duration of intermediate (a) and return flights (b) of Myotis emarginatus of the Lockenhaus maternity colony over the whole study period.

Obr. 1. Průměrná doba trvání intermediátních (a; viz Methods) a návratových letů netopýrů brvitých (Myotis emarginatus) lockenhauské kolonie během celého studovaného období. 


\section{RESULTS}

\section{Timing and duration (Table 1)}

Over the study period, adult female Geoffroy's bats arrived at the maternity roost after arousal from hibernation between 21 and 27 April, mean date: 24 April. The mean duration of annual roost occupancy by the whole colony (adult plus juvenile bats) was 96.5 days with an inter-annual variation of 20 days. This variation was primarily determined by the length of the post-lactation period.

The mean duration of reproduction (pregnancy and lactation) was 73 days with an inter-annual variation of 7 days. Thus, reproductive activities of adult females occupied about ca. one fifth of the year. The maximum inter-annual difference in the duration of colony formation (prA) amounted to 10 days; that of the whole pregnancy period (prAB) to five days, and of lactation to six days. The mean date of the onset of parturitions was 9 June, the mean day of the onset of the post-lactation period was 5 July. As Fig. 1b shows, the final, almost simultaneous departure from the roost by adult females occurred a few days after weaning. Already highly developed dead juveniles found in the roost indicate that some already departed females had abandoned their not yet independent young. The duration of roost occupancy by juvenile bats during post-lactation was characterised by large differences between the study years (maximum inter-annual difference 22 days). The longest stay (in 2015) was almost three times longer than the shortest stay (in 2012).

\section{Influence of we ather}

Adult female Geoffroy's bats showed high fidelity to their maternity roost. Substantial drops in ambient temperature and rain causing poor foraging conditions and probably torpor resulted, however, in more or less marked temporary reductions in the numbers of roost occupants returning to the roost in the morning in relation to the numbers that had left the roost in the evening before (Fig. 2). Complete absence from the roost for one or more $24 \mathrm{~h}$-days as a response to heavy rain and very low ambient temperatures was also observed.

Table 1. Timing and duration of stay in the roost (DR), duration (prA) and end (EC) of colony formation, duration of pregnancy (prAB), onset (OL) and duration (DL) of lactation, and onset (OP) and duration (DP) of post-lactation (days) of Myotis emarginatus of the Lockenhaus maternity colony

Tab. 1. Načasování a trvání doby strávené v úkrytu (DR), doba (prA) a ukončení (EC) doby utváření kolonie, trvání břrezosti (prAB), začátek (OL) a doba trvání (DL) laktace a začátek (OP) a doba trvání (DP) postlaktace (ve dnech) netopýrů brvitých (Myotis emarginatus) lockenhauské kolonie

\begin{tabular}{lcrrrrrrrrr}
\hline $\begin{array}{l}\text { year } \\
\text { rok }\end{array}$ & $\begin{array}{l}\text { arrival } \\
\text { pŕílet }\end{array}$ & $\begin{array}{c}\text { departure } \\
\text { odlet }\end{array}$ & DR & prA & EC & prAB & OL & DL & OP & DP \\
\hline 2012 & 26 April & 17 July & 84 & 12 & 6 May & 45 & 9 June & 27 & 6 July & 12 \\
2013 & 27 April & 2 August & 99 & 13 & 8 May & 47 & 12 June & 24 & 6 July & 28 \\
2014 & 22 April & 23 July & 94 & 12 & 2 May & 47 & 7 June & 26 & 3 July & 21 \\
2015 & 23 April & 3 August & 104 & 16 & 7 May & 48 & 9 June & 22 & 1 July & 34 \\
2016 & 21 April & 28 July & 100 & 20 & 9 May & 50 & 9 June & 28 & 7 July & 22 \\
2017 & 26 April & 31 July & 98 & 22 & 16 May & 48 & 12 June & 26 & 8 July & 24 \\
\hline
\end{tabular}



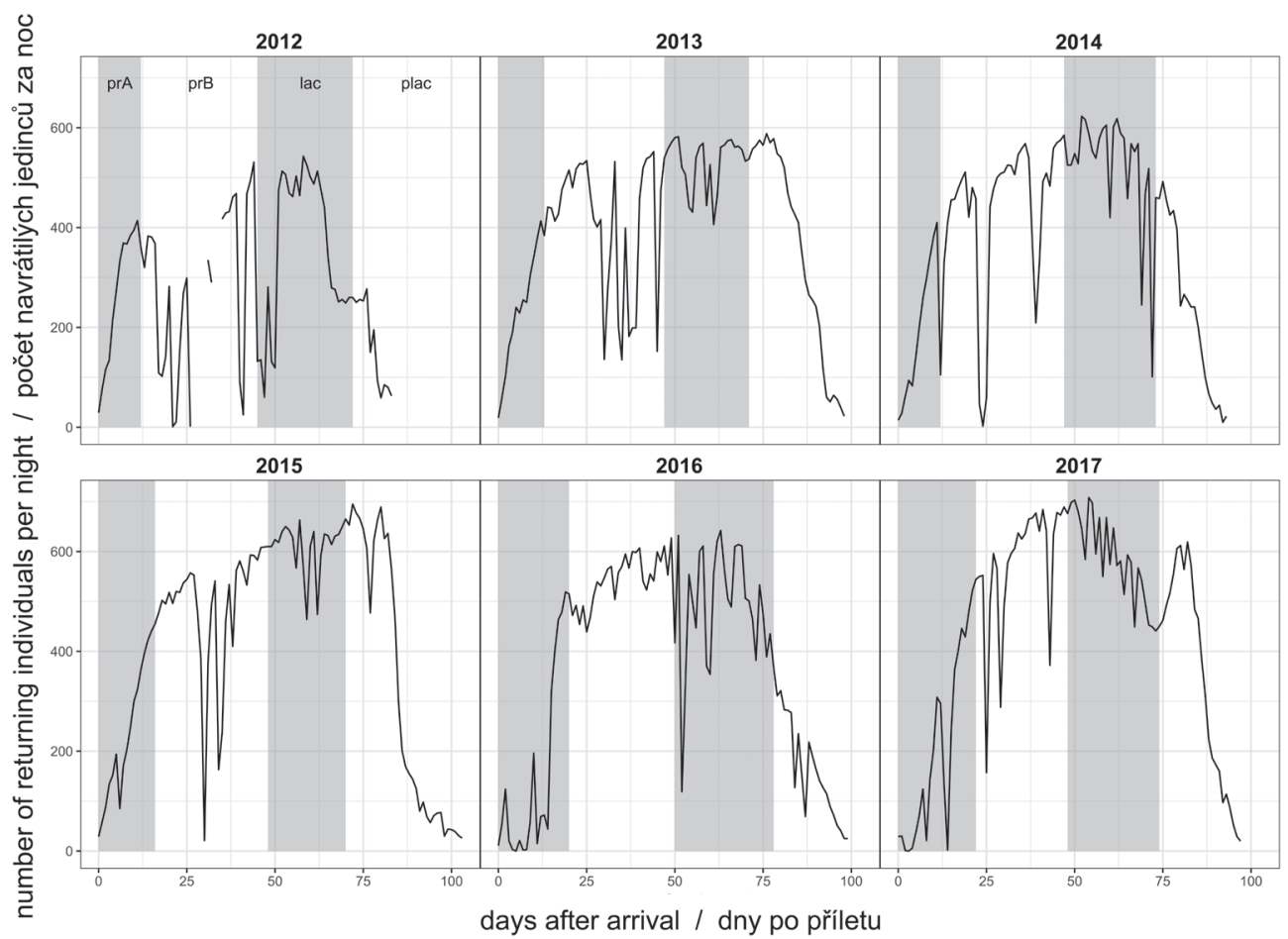

Fig. 2. Number of adult females of Myotis emarginatus returning to the Lockenhaus maternity roost per night. Background shading denote the reproductive phases of colony formation (prA), late pregnancy (prB), lactation (lac), and post-lactation (plac).

Obr. 2. Počet dospělých samic netopýrů brvitých (Myotis emarginatus) vracejících se do úkrytu lockenhauské kolonie za noc. Různá zastínění pozadí grafu označují fase utváření mateřské kolonie (prA), pozdní březosti (prB), laktace (lac) a postlaktační fasi (plac).

The date of onset of annual roost occupancy was not influenced by the recorded weather variables. On initial arrival nights, the median $\mathrm{T}_{\mathrm{a}}$ ranged between $10.5^{\circ} \mathrm{C}$ and $18.4^{\circ} \mathrm{C}$. As the following two examples show, weather did influence the final departure of the colony from the roost. In 2012, the year with the shortest stay ( 84 days), short rain showers occurred from 9 to 10 July, few rainfalls lasting 1-2 hours were recorded from 11 to $13 \mathrm{July}$, and from 14 July afternoon to noon of 15 July it was constantly raining; a severe drop in $\mathrm{T}_{\mathrm{a}}$ lowered the average night temperature from $20.0^{\circ} \mathrm{C}$ on 12 July to $14.2^{\circ} \mathrm{C}$ on $17 \mathrm{July}$, and the average $\mathrm{T}_{\mathrm{r}}$ during daytime from $28.2^{\circ} \mathrm{C}$ on 12 July to $18.5^{\circ} \mathrm{C}$ on 15 July. This adverse weather spell diminished the numbers of females remaining in the roost dramatically (from about 500 to 25). On 16 July, the adult females had already terminated their stay in the roost. The remaining young (about 200) left the roost one day later or died. The longest stay in the roost (104 days) was recorded in 2015. While adult females left the roost already on 30 June, juveniles stayed in the roost 
until 3 August. With the exception of three incidences of rainfall in July, summer weather was hot and dry in this year. Between 9 July and 4 August, the temperature rose continuously and may have caused the juvenile bats to stay longer in the roost.

A relation between the length of the reproductive period and occurrence of inclement weather during the reproductive phases is not suggested by our data. The only phase clearly affected by adverse weather conditions was the colony formation (prA; Table 1). In the years 2012-2015, when no or only minor temperature reductions occurred in the first two weeks after initial arrival in the roost, colony formation was completed in 12-16 days. In 2016 and 2017, however, severe cold spells prolonged the duration of colony formation to 20 and 22 days, respectively. In spite of cold weather spells occurring to a varying extent and number during pregnancy after colony formation (Fig. 2), the inter-annual variation of the duration of the total pregnancy period was small (45-50 days) (Table 1).

Despite single adverse weather spells at the beginning of lactation in 2012 and 2016, the duration of the total lactation period varied between 22 and 28 days over the study years. It was shortest in 2015, the year with the longest post-lactation period, and longest in 2012, the year

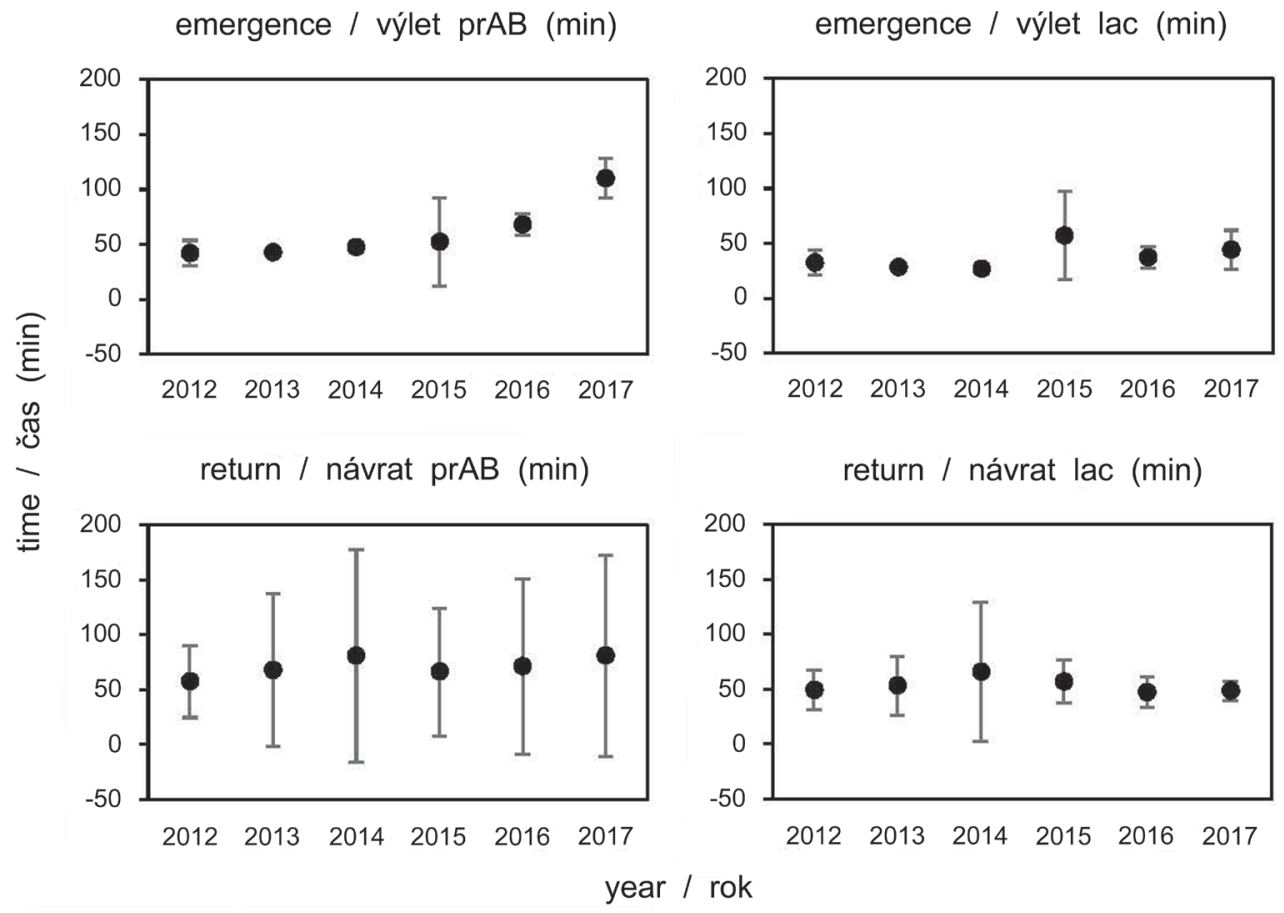

Fig. 3. Mean duration of emergence and return flights of Myotis emarginatus of the Lockenhaus maternity colony during pregnancy (prAB) and lactation in the years 2012-2017.

Obr. 3. Průměrná doba trvání výletu a návratu lockenhauské kolonie netopýrů brvitých (Myotis emarginatus) v průběhu březosti (prAB) a během období laktace v letech 2012-2017. 
with the shortest post-lactation period. During the post-lactation periods, inclement weather spells occurred only in 2012 and caused early departure of the juveniles.

\section{Durations of night activities (Fig. 3)}

During pregnancy, emergence and return flights lasted longer than during lactation. Over the study period, the mean annual duration of emergence was 61 min during pregnancy (prAB), and 37 min during lactation; the mean durations of emergence during the phases $\mathrm{A}$ and $\mathrm{B}$ of pregnancy were $79 \mathrm{~min}$ and $52 \mathrm{~min}$, respectively. In the years 2012-2015, Geoffroy's bats kept the mean duration of emergence quite similar, but it increased distinctly in 2016 and 2017. A similar, but less pronounced pattern is indicated in emergence flights during lactation. With the exception of the year 2015, the intra-annual standard deviations of the mean length of emergence events during pregnancy and lactation were generally low.

Over the study period the mean duration of return was 71 min during pregnancy (prAB) and 53 min during lactation. The inter-annual variation of the duration of return was larger during pregnancy than during lactation. As shown by high standard deviations, the annual variation of the length of return flights during pregnancy (pregAB) was large. Over the study period, the mean duration of return flights during colony formation (prA) was $130 \mathrm{~min}$, after colony formation $43 \mathrm{~min}$. With the exception of the year 2014, the annual standard deviations of return flights during lactation were clearly smaller than during pregnancy.

Over the study period, the mean nocturnal absence from the roost per night lasted six hours and 13 min ( $373 \mathrm{~min} ; \mathrm{n}=573$ ) with a maximum inter-annual difference of $18 \mathrm{~min}$. It was slightly shorter during lactation (366 min) than during pregnancy (pregAB) (387 min; Fig. 4).

During post-lactation, the mean annual duration of return flights carried out mainly by juveniles differed distinctly from those conducted by adult females during pregnancy and lactation. Over the study period, the mean emergence length and mean time spent outside the roost were short (45 min and $354 \mathrm{~min}$, respectively), the mean duration of return, however, was extraordinarily long (273 $\mathrm{min})$.

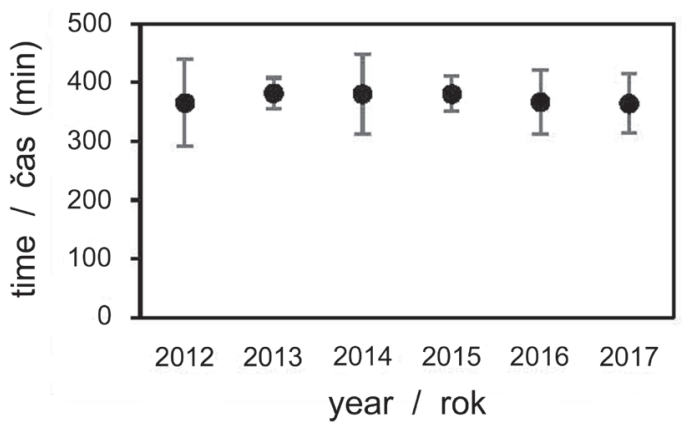

Fig. 4. Mean duration (in minutes) of time spent by Myotis emarginatus of the Lockenhaus maternity colony outside the roost in the years 2012-2017.

Obr. 4. Průměrná doba (v minutách) strávená netopýry brvitými (Myotis emarginatus) lockenhauské kolonie mimo jejich úkryt v letech 2012-2017. 


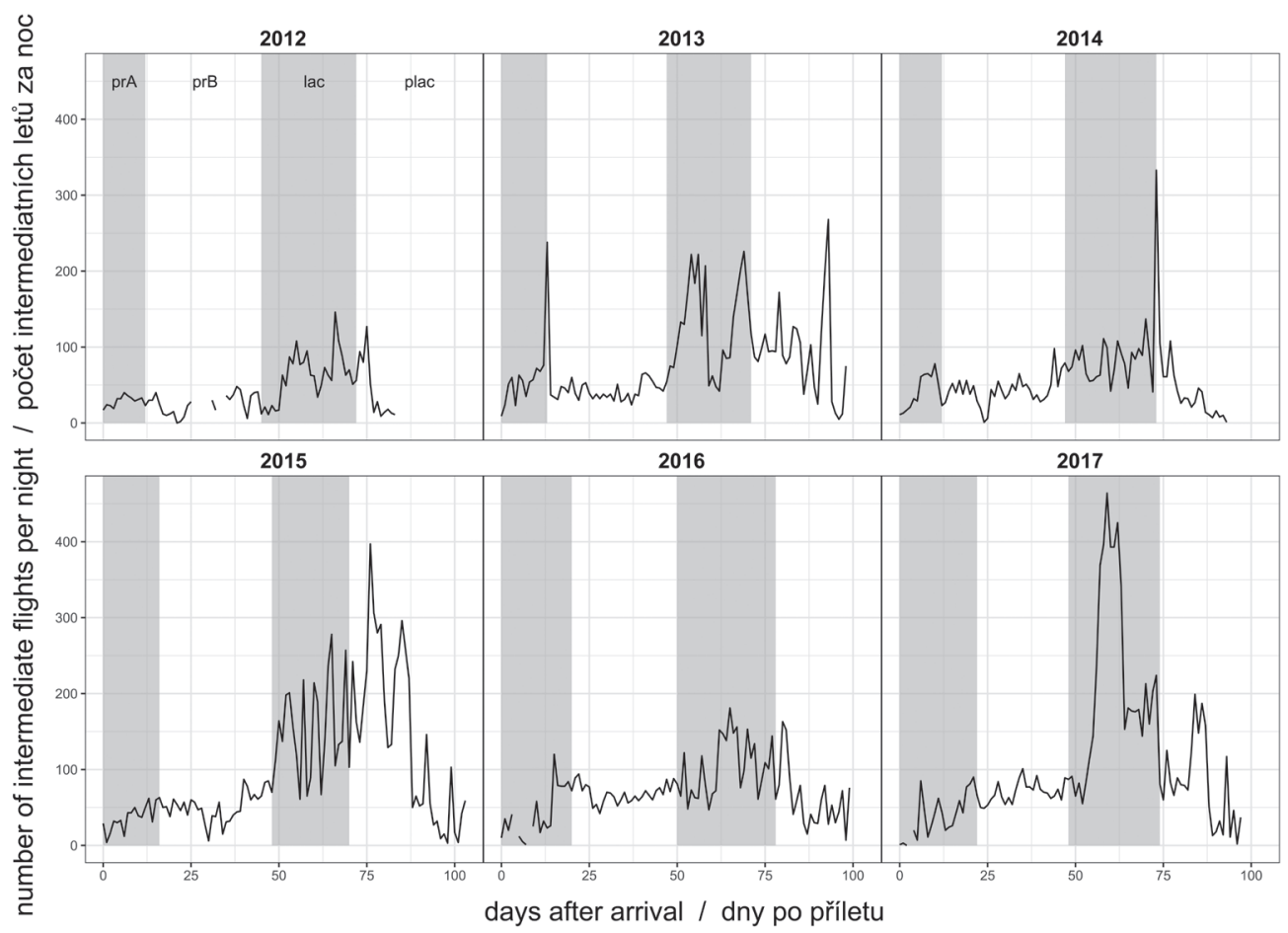

Fig. 5. Number of intermediate flights performed by females of Myotis emarginatus of the Lockenhaus maternity colony during lactation in the years 2012-2017. Background colours denote the reproductive phases of colony formation ( $\mathrm{prA}$ ), late pregnancy (prB), lactation (lac), and post-lactation (plac).

Obr. 5. Počet intermediátních letů provedených netopýry brvitými (Myotis emarginatus) lockenhauské kolonie v průběhu laktace v letech 2012-2017. Různá zastínění pozadí grafu označují fase utváření mateřské kolonie (prA), pozdní březosti (prB), laktace (lac) a postlaktační fasi (plac).

\section{Reproductive output and juvenile mortality}

Considerable differences in the magnitude of increase of intermediate flights during lactation (Fig. 5) indicate that the annual reproductive output was strongly fluctuating and generally low. It was definitely the highest in 2017 when the visual counts of the total numbers of juveniles resulted in 361 juveniles per 679 adult females i.e. 51.8\%. Using the reproductive output in 2017 as a reference, the yearly reproductive output was very moderate in 2012,2014, and 2016, and medium in 2013 and 2015.

Juvenile mortality was mainly observed during energy bottle necks as a consequence of harsh weather conditions in spring and abandonment of late born young by their mothers before their departure in July. In 2012, the total amount of dead young of all age groups was 45, in 2017 it was 71 cases. Between 13 and 16 July 2012 we noted 21 dead probably incompletely weaned young which had been abandoned by their mothers. In 2017, parturition started around 12 June. On this day, we found besides one living young on the beam where the colony mostly roosted, 
23 aborted foetuses on the floor. Between 12 and 26 June 2017 we collected 34 aborted foetuses and 11 mostly neonatal juveniles.

Development of the peak colony size

The average maximum number of adult females increased from more than 500 in 2012 to almost 700 in 2017 (Fig. 6). Irregularly observed juvenile mortality and the general low percentage of lactating mothers imply a high proportion of non-reproductive females in the colony.

\section{DISCUSSION}

Compared to sympatric Myotis daubentonii and M. nattereri with whom M. emarginatus shares some basic life history traits and large parts of the distribution area, the adjustment of the phenology of reproductive activities to extrinsic factors such as weather, was low in the studied maternity colony of Geoffroy's bats. As in many other vespertilionid bats (e. g. RACEY \& SwiFt 1981, Grindal et al. 1992, Burles et al. 2009), reproductive activities conducted by Myotis daubentonii and M. nattereri are strongly influenced by weather. In South Bohemia, dates of first parturitions of $M$. dubentontonii were related to ambient temperature in April and varied by 24 days over a 14 year study period (LuČAN et al. 2013). In England, mean dates of parturitions of $M$. nattereri varied by 38 days and of $M$. daubentonii by 30 days over an 11 year study period (LiNTON \& MACDONALD 2018).

Contrary to those species, activities carried out by adult female Geoffroy's bats during reproduction followed quite strict annual and diel temporal patterns every study year, despite distinct

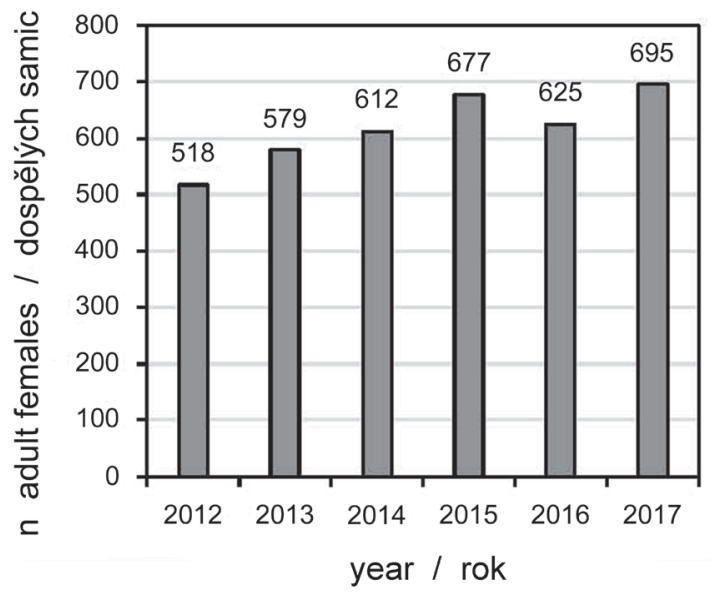

Fig. 6. Maximum numbers of adult females of Myotis emarginatus in the Lockenhaus maternity roost in the years 2012-2017.

Obr. 6. Nejvyšší počty jedinců netopýrů brvitých (Myotis emarginatus) lockenhauské kolonie v průběhu let 2012-2017. 
inter-annual differences in the occurrence of adverse weather spells which caused abandonment of the maternity roost and probably use of torpor for energy saving in alternate roosts. Determined was the phenology of roost occupancy and reproductive periods. The inter-annual variation of duration of the pregnancy period was only 5 days despite significantly different lengths of colony formation during early pregnancy. Bats maintained nocturnal activities such as duration of emergence and return flights, and time spent outside the roost rather similar over the six observed pregnancy and lactation periods. Only the duration of emergence flights increased conspicuously with increasing numbers of roost inhabitants. The activity patterns of weaned juveniles during post-lactation were similar to those conducted by adult females, but the duration of return flights was considerably longer.

Interestingly, the mean duration of the energetically very costly lactation period was $53 \%$ of the gestation period, and the mean time spent outside the roost was a little shorter during lactation than during pregnancy. This suggests that the increased energy costs during lactation were not met by an increased food intake. The departure of adult females from the roost after (or sometimes even prior to) termination of weaning of all juveniles may serve to reduce competition for food (KunZ 1974).

The proportion of females which terminated reproduction successfully was smaller in Geoffroy's bats than in Myotis daubentonii and M. nattereri. In South Bohemian M. daubentonii, the mean value of reproductive success was 75\% (range 33-93\%; LUČAN et al. 2013) and in English M. daubentonii older than one year the mean proportions were 0.73, and 0.92 in English M. nattereri older than one year (LinTON \& MACDONALD 2018). In contrast, the reproductive output of the Lockenhaus maternity colony of Geoffroy's bats over the whole study period was $<52 \%$. Low reproductive output was also reported from maternity colonies of $M$. emarginatus in Upper Bavaria (RichARZ et al. 1989) and Baden-Württemberg (BRinKMANN et al. 2002).

The observed low flexibility in the activity pattern of Geoffroy's bats during reproduction indicates that this species relies solely on the photoperiod as a cue for the internal clock. The principal advantage of this cue is the creation of synchronisation of all activities carried out by all maternity roost mates. Starting and ending annual and diel activities at the same time is an important prerequisite for effective social thermoregulation which in turn is an important mechanism for compensation of energy bottle necks caused by adverse weather (ROVERUD \& ChAPpell 1991, Gilbert et al. 2010). The well known behaviour of continuous huddling in large clusters in the maternity roost (RicharZ et al. 1989, ZAHN \& HENATSCH 1998, and own data) can thus be viewed as compensation for adverse torpor effects on the length of gestation Geoffroy's bats suffered during periods of food shortage. The presence of non-reproductive females in the huddling cluster increased the effect of social thermoregulation by increasing the size of the group especially during lactation when energetic costs are highest. As the nonbreeding females exhibited socially coordinated behaviour by adjusting their actions to the activities of the reproductive roost members, they can be regarded as helpers of the breeding females (CLuTtON-Brock 2002).

We hypothesise that in the trade-off between the life history traits (survival and reproduction), Geoffroy's bats clearly optimise survival by completing reproduction early to allow for a long hibernation period at the expense of high reproductive success. Strict adherence to the photoperiod created synchronisation of activities carried out by all roost mates which enabled effective social thermoregulation as a compensation for detrimental effects of torpor used as energy saving mechanism during bouts of inclement weather. 


\section{SOUHRN}

Za pomoci infračervené světelné bariéry a videozáznamů infračervenou kamerou (a také občasných př́ímých sčítání jedinců v úkrytu) jsme studovali časový průběh sezonní a denní aktivity kolonie netopýra brvitého (Myotis emarginatus) během rozmnožování v letech 2012-2017. Snažili jsme se určit vliv počasí na délku doby, kterou netopýři trávili v úkrytu, na načasování jednotlivých fasí rozmnožovacího období, na načasování a délku doby výletů z úkrytu, návratů zpět a doby strávené mimo ukryt, a také jsme se pokusili určit každoroční reprodukční úspěšnost kolonie. Na rozdíl od značného účinku povětrnostních podmínek na reprodukční fenologii netopýra vodního (Myotis daubentonii) a netopýra řasnatého (Myotis nattereri) byla načasování a trvání reprodukčních aktivit netopýra brvitého v celém průběhu sledování pozoruhodně podobná, a to i přes výrazné meziroční rozdíly ve výskytu nepříznivých údobí způsobujících nedostatek potravy a nutících netopýry navodit dočasnou strnulost (torpor). Březost, laktace a př́tomnost dospělých samic v kolonii vůbec každoročně trvala 10 až 11 týdnů. Nepř́znivé povětrnostní podmínky na jaře působily značné výkyvy $\mathrm{v}$ trvání utváření kolonie $\mathrm{v}$ průběhu rané březosti, ale neovlivnily celkové trvání doby březosti. Průměrná délka doby výletu kolonie, jakož i doby návratu kolonie byla v průběhu sledování velmi podobná. Výjimkou bylo výrazné prodloužení doby výletu kolonie v průběhu březosti v letech 2016 a 2017, které by ovšem mohlo souviset se zvýšením počtu samic v kolonii. Kromě roku 2015 byly standardní odchylky trvání doby výletu kolonie malé. Na rozdíl od docela přesně časovaných návratů samic do kolonie $\mathrm{v}$ průběhu laktace se velmi různily průměrné doby trvání návratu v průběhu březosti. Časování návratů vzletných mlád’at v postlaktačním období byly velmi nepravidelné. Průměrné noční doby strávené netopýry mimo jejich úkryt byly v celém průběhu sledování dosti podobné. Odhadovaná roční reprodukční úspěšnost kolonie byla nízká $(<52 \%)$ a podíl nerozmnožujících se samic v mateřské kolonii vysoký. Na druhou stranu, počet netopýrů v kolonii během studovaného období značně vzrostl. V závěru studie je diskutován význam udržování poměrně nepružného časového nastavení průběhu sezonních a denních aktivit a účinné sociální thermoregulace $\mathrm{v}$ kolonii ve vztahu k rovnováze mezi úspěchem přežití a reprodukce.

\section{Acknow ledgements}

We are grateful to the board of trustees of the Prof. Paul Anton Keller-foundation/Burg Lockenhaus for constant and friendly support, and we thank Tony MitCHELL-JONES for helpful remarks and improving the English. Description of the working system of the light barriers was contributed by Karl KUGELSCHAFTER, the calculation of the time spent outside the roost was provided by Simon ENGELBERGER who computed the data and prepared the Figs. 1, 2, and 5.

\section{REFERENCES}

BAUER K., 1957: Neue Funde der Wimperfledermaus, Myotis emarginatus (Geoffroy, 1806), in Österreich. Säugetierkundliche Mitteilungen, 5: 97-100.

Brinkmann R., Hensle E. \& Steck C., 2001: Artenschutzprojekt Wimperfledermaus. Untersuchungen zu Quartieren und Jagdhabitaten der Freiburger Wimperfledermauskolonie als Grundlage für Schutz- und Entwicklungsmaßnahmen. Landesanstalt für Umweltschutz, Freiburg \& Karlsruhe, 48 pp.

Burles D. W., Brigham R. M., Ring R. A. \& Reimchen T. E., 2009: Influence of weather on two insectivorous bats in a temperate Pacific Northwest Rainforest. Canadian Journal of Zoology, 84: 132-138.

Clutton-Brock T., Albon S. \& GuinNess F., 1989: Fitness costs of gestation and lactation in wild mammals. Nature, 337: 260.

ERKert H., 1982: Ecological aspects of bat activity rhythms. Pp.: 201-242. In: Kunz T. H. (ed.): Ecology of Bats. Plenum Press, New York \& London, 472 pp.

GAISLER J., 1971: Zur Ökologie von Myotis emarginatus in Mitteleuropa. Decheniana-Beihefte, 18: 71-82. Geiser F., 2013: Hibernation. Current Biology, 23: R188-R193. 
Gilbert C., McCafferty D., Le Maho Y., Martrette J. M., Giroud S., Blanc S. \& Ancel A., 2010: One for all and all for one: the energetic benefits of huddling in endotherms. Biological Reviews of the Cambridge Philospohical Society, 85: 545-569.

Grindal S., Collard D. T. S., Brigham R. M. \& Barclay R. M. R., 1992: The influence of precipitation on reproduction by Myotis bats in British Columbia. American Midland Naturalist, 128: 339-344.

Halle S. \& Stenseth N., 2000: Introduction. Pp.: 3-16. In: Halle S \& Stenseth N. (eds.): Activity Patterns in Small Mammals. An Ecological Approach. Ecological Studies 141. Springer, Berlin \& Heidelberg, $321 \mathrm{pp}$.

Helm, B., Ben-Shlomo R., Sheriff M. J., Hut R. A., Foster R., Barnes B. M. \& Dominoni D., 2013: Annual rhythms that underlie phenology: biological time-keeping meets environmental change. Proceedings of the Royal Society B: Biological Sciences, 280(20130016): 1-10.

Hood W. R., Bloss J. \& Kunz T.H., 2002: Intrinsic and extrinsic sources of variation in size at birth and rates of postnatal growth in the big brown bat Eptesicus fuscus (Chiroptera: Vespertilionidae). Journal of Zoology, London, 258: 355-363.

Hut R. A., Dardente H. \& Riede S. J., 2014: Seasonal timing: how does a hibernator know when to stop hibernating? Current Biology, 24: R602-R605.

Kretzschmar F., 2003: Wimperfledermaus Myotis emarginatus (Geoffroy, 1806). Pp.: 396-405. In: Braun M. \& Dieterlen F. (eds.): Die Säugetiere Baden-Württembergs. Eugen Ulmer, Stuttgart, 687 pp.

Krull D., Schumm A., MetzNer W. \& Neuweiler G., 1991: Foraging areas and foraging behavior in the notch-eared bat, Myotis emarginatus (Vespertilionidae). Behavioral Ecology and Sociobiology, 28: 247-253.

Kugelschafter K. \& Hensle E., 2017: The duration of hibernation of indigenous bat species - results of multiannual field research. P.: 80. In: Bärmann E., Begall S., Benke H., Dammann P., Giere P., Hackländer K., Kerth G., Langner C., Schönherr H., Ulrich R. G., Zachos F. \& Bussmann (eds.): 91st Annual Meeting. Deutsche Gesellschaft für Säugetierkunde (DGS). Friedrich-Loeffler-Institut, University Greifswald, Ozeaneaum Stralsund, Tierpark Greifswald, \& Zoo Stralsund, Greifswald \& Stralsund, $169 \mathrm{pp}$.

Kunz T. H., 1974: Feeding ecology of a temperate insectivorous bat (Myotis velifer). Ecology, 55: 693-711.

Kunz T. H. \& Stern A. A., 1995: Maternal investment and post-natal growth in bats. Symposia of the Zoological Society of London, 67: 693-711.

Kunz T. H., Wrazen J. \& BurnetT C. A., 1998: Changes in body mass and fat reserves in pre-hibernating little brown bats (Myotis lucifugus). Ecoscience, 5: 8-17.

Linton D. M. \& MACDONALD D.W., 2018: Spring weather conditions influence breeding phenology and reproductive success in sympatric bat populations. Journal of Animal Ecology, 87: 1080-1090.

LuČAN R. M., WeISER M. \& HANÁK V., 2013: Contrasting effects of climate change on the timing of reproduction and reproductive success of a temperate insectivorous bat. Journal of Zoology, London, 290: $151-159$.

MAIER C., 1992: Activity patterns of pipistrelle bats (Pipistrellus pipistrellus) in Oxfordshire. Journal of Zoology, London, 228: 69-80.

Moyes K., Morgan B., Morris A., Morris S., Clutton-Brock T. \& Coulson T., 2011: Individual differences in reproductive costs examined using multi-state methods. Journal of Animal Ecology, 80: 456-465.

RACEY P., 1969: Diagnosis of pregnancy and experimental extension of gestation in the pipistrelle bat, Pipistrellus pipistrellus. Reproduction, 19: 465-474.

RACEY P., 1973: Environmental factors affecting the length of gestation in heterothermic bats. Journal of Reproduction and Fertility, Supplement 19: 175-189.

Racey P. A. \& Speakman J. R., 1987: The energy costs of pregnancy and lactation in heterothermic bats. Symposia of the Zoological Society of London, 57: 107-125.

RACEY P. A. \& SWIFT S. M., 1981: Variations in gestation length in a colony of pipistrelle bats (Pipistrellus pipistrellus) from year to year. Journal of Reproduction and Fertility, 61: 123-129. 
Ransome R. D., 1995: Earlier breeding shortens life in female greater horseshoe bats. Philosophical Transactions of the Royal Society of London B, 350: 153-161.

Richarz K., Krull D. \& Schumm A., 1989: Quartieransprüche und Quartierverhalten einer mitteleuropäischen Wochenstubenkolonie von Myotis emarginatus (Geoffroy 1806) im Rosenheimer Becken, Oberbayern, mit Hinweisen zu den derzeit bekannten Wochenstubenquartieren dieser Art in der BRD. Myotis, 27: 11-113.

Roverud R. C. \& Chappell M. A., 1991: Energetic and thermoregulatory aspects of clustering behavior in the Neotropical bat Noctilio albiventris. Physiological Zoology, 64: 1527-1541.

StEarn S. C., 1989: Trade-offs in life-history evolution. Functional Ecology, 3: 259-268.

STECK C. \& BRINKMANn R., 2015: Wimperfledermaus, Bechsteinfledermaus und Mopsfledermaus: Einblicke in die Lebensweise gefährdeter Arten in Baden-Württemberg. Haupt Verlag, Berlin, 200 pp.

Topál G., 2001: Myotis emarginatus (Geoffroy, 1806). Pp.: 369-404. In: Niethammer J. \& Krapp F. (eds.): Handbuch der Säugetiere Europas 4/1. Aula Verlag, Wiebelsheim, 602 pp.

Turbill C., Bieber C. \& Ruf T., 2011: Hibernation is associated with increased survival and the evolution of slow life histories among mammals. Proceedings of the Royal Society B: Biological Sciences, 278: $3355-3363$.

WiLKINSON G. S. \& South J. M., 2002: Life history, ecology and longevity in bats. Aging Cell, 1: 124-131.

Zahn A. \& HenATsch B., 1998: Bevorzugt Myotis emarginatus kühlere Wochenstubenquartiere als Myotis myotis? Zeitschrift für Säugetierkunde, 63: 26-31. 